\title{
Economics approaches the fork in the road. Labor self-financing and tax free compensations or toil of deficit and deflation
}

\author{
Mieczysław Dobija \\ Faculty Management, Cracow University of Economics, Ul. Rakowicka 27, 31-510 Cracow \\ E-mail: dobijam@uek.krakow.pl
}

\begin{abstract}
The aim of this paper is pointing out the causes of persistent budget deficits, and the emergence of deflation. As a result of the theoretical analysis of capital and labor tandem the phenomenon of labor self-financing is revealed. Discerning the money-goods economy in the form of the two parallel streams of products, and money lead to the alternative equation of exchange, which indicates an acceptable credit size? The main outcome of this study is clarify that deflation is related to funding of work in the public sector by taxes. It results in imbalance between the value of the product and the money streams. If inflation is under control then deflation reveals itself. Additionally it is concluded that economics without deficit, inflation and deflation may exist. It is further claimed that in the present economics there is a correspondence between the amount of necessary issuance of money and the amount of salaries in the public sector.
\end{abstract}

Keywords: Capital; Labor; Earnings; Deficit; Deflation.

\section{Introduction}

The threat of deflation occurs mainly in economically developed countries. Deflation occurs from two decades in Japan, a few years threaten the US, and now it appears in the economies of Western Europe. It is a phenomenon that is associated with a decrease in the aggregate demand. Thus, also the compensations and taxes on compensations. The main hypothesis considered in this article is a need to change the method of financing labor of the public sector in order to maintain a stability of the monetary unit. By nature of capital and labor work is financing on its own. In contrast, the charging of fair remuneration by direct tax excessively reduces demand, which causes the deflationary results and others bad effects.

Natural question arises why the demand is insufficient in the current system? After all, investments, production and sales should, in accordance with the Say's law, generate sufficient demand. Do not employees care about their own business now and do not they demand their wage rising? One of the suggestions make in this paper holds that the direct taxes apply to fair remuneration amend it in the unfair one, that is to say too low. The increasing efficiency of developed economies means that wages are adequate for the value of work, which in turn is a function of employee's human capital.

As commonly known, J.M. Keynes held that the Say's law does not work. This assertion is not natural ; because this law is a basic and even fundamental, so it does not require any evidence but a regard and respect. It is Keynes' theory that does not work correctly, not the Says' law. In other words , incorrect theories disturb a smooth working of the natural Says' law. W. J. Baumol's (1999) analysis indicates that this law is the work of many scholars starting with A. Smith, who is the main initiator. The essence of fundamental laws in the context of economics is discussed in more detail in (Kurek, Dobija, 2013). In the context of physical sciences, if a construction of building meets a disaster, nobody say that the law of universal gravitation is erroneous and constant $G$ is inadequate, but the professionals are looking for an error in the design, calculations and construction. They come to clear conclusion. The economics are far from a similar approach, theories are weak, which makes the money-goods economy reveals various shortcomings associated with incomplete understanding of the basic categories, such as: capital, labor and wages, as well as the nature of money.

Many scholars have not shared the opinion of J.M. Keynes, as presented in their serious analysis. For example, S. Kates (1998), who in the subtitle of his work puts the issue; "How Macroeconomic Theory lost its Way". W. H. Hutt (1974) wrote a significant book, "Rehabilitation of Say's Law ". It is natural that if economic difficulties arise, for example, reveals a lack of demand, then we should ask whether wages are fair or excessive tax burden earnings or maybe earnings of the rich people create a demand mainly outside the country. We can even ask for a lot of other issues relating to the deflation. In this study the subject of analysis and considerations are the issues why there are persistent budget deficits and why currently appear tendencies to an increase of deflation. Therefore, on the threshold, an agenda of the fair compensation should be theoretically examined. 


\section{A disclosure of economic constant of poten- tial growth}

Even in the days of Republican Rome, we found proofs of disputes between creditors and debtors and the relevant legal decision. According to A. Pikulska-Robaszkiewicz (1999, p. 41) in Republican Rome legal rate of interest, taking into account the interest of the parties and the physical environment was defined as $1 / 12$ of the initial capital, i.e. at the level of $8.3 \%$. In economics, particularly finance there is known a number that was called the "market risk premium" or "premium from the capital." Still appear publications like (Goetzmann\&Ibbotson, 2014) and many others, in which the authors seek to estimate the size of this premium, perceived as an appropriate rate of return on invested capital. In fact, the authors examine the percentage rate of return over riskfree. The latter usually defines short-term government bonds. Not everyone, however, accepts that there is a risk free rate, and then it is simply the rate of return. Significant historical study and investigation of the size of the risk premium achieved by investing in shares are presented by (Goetzmann\&Ibbotson 2005). These estimates are used in this study. However, adding my own interpretation, as shown in the Table 1.

Table 1: Average Rates O Return in the USA. Years 1926-2004.

\begin{tabular}{lllll}
\hline & \multirow{2}{*}{ Variable } & $\begin{array}{l}\text { Arithmetic aver- } \\
\text { age }\end{array}$ & $\begin{array}{l}\text { Geometric aver- } \\
\text { age }\end{array}$ & $\begin{array}{l}\text { Standard devia- } \\
\text { tion }\end{array}$ \\
\hline 1 & Stocks & $12,39 \%$ & $10,43 \%$ & $20,31 \%$ \\
2 & T-Bills & $3,76 \%$ & $3,72 \%$ & $3,14 \%$ \\
3 & Inflation & $3,12 \%$ & $3,04 \%$ & $4,32 \%$ \\
$\begin{array}{l}\text { Computations } \\
4\end{array}$ & & & \\
5 & $(1)-(3)$ & $9,27 \%$ & $7,39 \%$ & Average $8,33 \%$ \\
\hline
\end{tabular}

The row 4 shows the average real rate of return on the shares computed from data belonging to years 1926-2004. The row 5 presents the differences between the real returns on stocks and government bonds T-Bills. We see that the real value of the TBills is close to zero. Assuming that there is no real opportunity to invest without any risk we interpret the size of $8.33 \%$, which is a simple arithmetic average, since $9.27 \%$ and $7.39 \%$ are credited with equal probability. Let us note that if we say that there exists a priori potential rate of return $p$, and $p=8 \%$, or 0.08 [1/year], which expresses the rate of accumulating initial capital, the value of investments in the amount of one dollar should be multiplied up to $1.0 \times[\mathrm{e} 0,08-1]=0.083287 \approx 0,0833$ and therefore estimated p should be equal to $8.33 \%$. Now we can discern compliance to two decimal places with the average value in line 4 . This high consistency is probably coincidental, but calculations show how significant is the estimate obtained.

Another study of the size of the rate of return has been made in the field of entrepreneurship by B. Kurek (2011, p. 122-125) and the accomplished estimations to a large extent refers to the previous one. The author studied adequately defined the ratio ROA. The ratio of profit (capital increase) to total capital included in the assets of a firm. Field studies were the balance sheets and the income statements of companies belonging to the Standard \& Poor's 1500. The author had access to the reports of 1500 companies in the time period of 20 years. However, the actual number of reports in the Compustat database was 22952 statement. The author conducted a statistical survey of putting the hypothesis that the average risk premium calculated with the ex post data is equal to $8.33 \%$. The survey results did not lead to rejection of the hypothesis. The confidence interval at confidence level 0,99 is $8.25 \%$ $8.89 \%$, while the mean is $8.57 \%$ with a standard deviation of $14.81 \%$. An assessment of the relative error does not exceed 5.0, since the relative precision of estimation equals to $3.75 \%$, which indicates that the statistical forecasting is safe (Kurek 2011, p 122-125). This author also examined reports for smaller collections, such as Standard \& Poor's 600 (small businesses) and Standard \& Poor's 400 (average), which yield similar results, the average respectively $7.41 \%$ and $8.85 \%$ but with a greater error evaluation, not excluding the statistical forecasting.

The estimation results lead to some questions about the source of profits. It is clearly, that profits on the shares have a source in corporate profits; this correlation is clear. Enterprises calculate depreciation of fixed assets, and usually they pay fairly for work of human capital, which in both cases does not allow the depreciation of capital. Companies pay for supplies and they also pay taxes to the external environment. We may find that reasonable management leads to a state in which all contractors of companies obtain appropriate part in the created surplus. If we do not admit any mistreatment, so what is the source of profits? Of course it's not like risk, which is the source of unforeseen costs and losses. The answer is natural; this potential lies in the Nature, which allows for the reproduction of capital and the creation of surplus value, as Physiocrats already knew. It is the Nature where the phenomenon of photosynthesis manifests itself, which uses of the solar energy and to produce carbohydrates. Thanks to photosynthesis the plants can develop as well the animal kingdom. Therefore human resources maintain their existence. The human capital, which is doing the work i.e. transferring the capital to work objects (products), and giving them an economic value is embodied in these resources. That is why the economy (Wright 2000, p. 3032 ) is seen as a game with Nature, which is a positive non-zero game where all participants can take part in the win. The size of the win estimates the constant of potential growth at the rate 0.08 [1/year]. This means that the capital which is embodied in the resources of various kinds can multiply at a yearly average rate of $8 \%$. It is a constant characterizing of the human existential space, called the economic constant of potential growth (ECPG).

A question arises, is that how to calculate a capital contained in the human resources? Let us examine a calculation of the minimum wage for the US using ECPG. It is assumed that in the US the legal minimum hourly wage is determined at an honest level, which allows the protection against the depreciation of human capital. Currently, this wage is US $\$ 7.25$ and together with the pension contribution it gives $7.25 \times 1.062=\$ 7.70$, since the employer pays a pension payment of $6.2 \%$. It is assumed that a teenager (17 years old) grew up in a family of four person's type $2+$ 2 . According to the survey an estimated value of monthly costs of living belongs to the interval [450\$, 500\$]. The amount of $\$ 475$ per person per month is chosen for our computations. Number of years of capitalization is 17. The calculations are placed in Table 2 . These computations provide also a simple test whether the value of ECPG is $8 \%$ provided that US minimum wage is fair. The potential value of teenager human capital joining the work at 17 teen is calculated by capitalizing the costs of living (while ignoring the baby, who is a natural good so is not a subject to economic calculation). The estimated human capital is 206354 \$.

Compensation is for the entrepreneur the cost of a use the human capital. Since capital as an abstract and potential category relies a natural dispersion, thus maintaining the value of human capital requires compensation equal to the expected diffusion with ratio $\mathrm{s}$. Scattering of capital is spontaneous and random. Its average value does not exceed $\mathrm{p}=0.08$ [1/year] otherwise destruction would overcome creating. Therefore yearly compensation $\mathrm{W}=\mathrm{s} \times \mathrm{H}(\mathrm{p})$ $\approx \mathrm{p} \times \mathrm{H}(\mathrm{p})=16598 \$$, where $\mathrm{s}$ determines the rate of random dispersion of capital, and $\mathrm{H}(\mathrm{p})$ denotes human capital. As a result, the calculations show almost $100 \%$ of consistency between the remuneration arising from the theory and practice of the real minimum wages. A change of the ECPG on plus or minus about 0.005 leads to excessive deviations. Assuming as the fair value the minimum wage in the US, it is concluded that the value of the constant $\mathrm{p}$ appearing in the formula $\mathrm{W}=\mathrm{p} \times \mathrm{H}(\mathrm{p})$ should be $\mathrm{p}=0.08$ [1/year].

The second part of Table 2 , confirms that the constant pay determined by the formula $\mathrm{W}=\mathrm{p} \times \mathrm{H}(\mathrm{p})$ as well as the real mandatory minimum pay are fair, that is to say this wage prevents an employee human capital depreciation. This opinion is confirmed by various studies, such as W. Kozioł (2009), W. Kozioł (2011, p 4780), J. Renkas (2012) and others. The essence of the research 
shows the calculations in the lower part of Table 2. If the minimum wage is 1376 \$ per month, the two parents earn at least 2752 $\$$. After paying pension contributions of $20 \%$ and $10 \%$ of the health monthly fee remains $1926 \$$. So for the four person's family $(2+2)$ the cost of living is at least $481.6 \$$ per person. It is more than the initial value $\$ 475$, so that the conditions of life are not worsening even at the absolute minimum wage. Pension contribution of $0.2 \times 1376 \$$ or $\$ 275.2$ capitalized at the real rate of $3 \%$ to 65 years of age or over 47 years will provide the pension found 331549 , which gives monthly pension at the minimum wage level for the next 20 years.

Table 2: Computations of Human Capital and Introductory Test That $\mathrm{ECPG}=0,08[1 /$ Year $]$

\begin{tabular}{|c|c|c|}
\hline Computed value & Computation formula & Issue \\
\hline $\begin{array}{l}\text { Capitalized cost of living at rate } \\
8 \% \text {. Continuous compounding }\end{array}$ & $\begin{array}{l}\mathrm{H}(\mathrm{p})= \\
12 \times 475[\mathrm{e} 17 \times 0.08- \\
1] / 0.08\end{array}$ & $\begin{array}{l}206354 \\
\$\end{array}$ \\
\hline Yearly cost of labor of teenager & $\mathrm{W}=\mathrm{s} \times \mathrm{H}(\mathrm{p}) \approx \mathrm{p} \times \mathrm{H}(\mathrm{p})$ & $16598 \$$ \\
\hline Monthly cost of labor & $\mathrm{MCL}=\mathrm{W} / 12$ & $1376 \$$ \\
\hline Hourly cost of labor (HCL) & $\mathrm{HCL}=\mathrm{MCL} / 176$ & $7.81 \$$ \\
\hline $\begin{array}{l}\text { HCL determined by minimum } \\
\text { wage legal act }\end{array}$ & $7.25 \times 1.062$ & $7.70 \$$ \\
\hline Family $(2+2)$ revenues & & \\
\hline Doubled minimum wage & $2 \times \mathrm{MCL}$ & $2752 \$$ \\
\hline $\begin{array}{l}\text { Minus contribution for pension } \\
\text { fund }(20 \%) \text { and health care } \\
(10 \%)\end{array}$ & $0.3 \times 2.752 \$$ & $1926 \$$ \\
\hline Cost of living per person & $1926 \$ / 4$ & $481.6 \$$ \\
\hline $\begin{array}{l}\text { Detriment fund for } 1 \text { person after } \\
43 \text { years capitalized at rate } 3 \%\end{array}$ & $\begin{array}{l}12 \times 275.2 \times \\
{[(1+0.03) 47-1] / 0.03}\end{array}$ & $331549 \$$ \\
\hline
\end{tabular}

At this point, we should ask why these findings are not consistent with the real state of affairs ?. Why pension fund is often too small, or not survived until retirement? Many causes explain the differences between theory and reality. Apart from the negative random events that cause that savings are inadequate and need social assistance is the lack of a reasonable personal health care is one of the important causes of higher spending. There are, however, independent economic reasons. Table 1 shows that the multiplication of capital invested in shares may reach an average of $8 \%$, so the assumption that pension contributions are capitalized at a rate of 3\% is deemed as moderate. It is known. However, that crises depreciate the value of pension funds invested in stocks. Why the crises and the sudden declines in the value of the most stocks and investment funds occur? There is only one answer, if theory of money allows, and the practice accepts the creation of capital out of nothing by the issuance of cash and money emission without any connection with work that is neither theory nor practice does not respect the fundamental laws of reality. In this situation, the nominal values generated over a certain level, will not be absorbed by the economy and must be annihilated. When a continuous process of inflation is not quite efficient crisis occurs, during which the market through the stock exchanges eliminates excess of the nominal value. The opposite phenomenon (increase of money unit value) can appear when the fair compensations are decreased by direct taxes.

What value of printed money can be absorbed by the economy? This is a value corresponding to the work done for the economy not yet paid (remaining without payment), in particular the work in the family sector of the economy. What is more, the value of work done in the public sector determines the amount that could be absorbed by the economy. Financing this work with taxes is theoretically incorrect, like charging wage by direct tax. Economy is after all the sum of capital flows, i.e. of the abstract capacity of doing a work (Dobija\&Kurek, 2013). Measuring and examining these flows is the essence of accounting and economics. The financial policy, fiscal policy and monetary policy are often the manifestations of the arrogance of authority and they usually win with the desires of the pursuit of scientific economics as determined by (Kurek\&Dobija, 2013).
Three areas of research and presented the historical reference point to the existence of a natural potential quantitatively expresses the ECPG. This kind of value called constant does not have a theory, but only numeric values. They are well known to science, such as mathematics, physics, chemistry, where they fulfill the important and indispensable role. It is worth recalling that the first discovered was constant $\mathrm{G}$, called the galactic constant, helped to determine the gravitational acceleration $g=9.81 \mathrm{~m} / \mathrm{sec} 2$. Scientists create different interpretations of the phenomenon of constants; some believe that these figures will disappear when the theory develops accordingly. J. Barrow (2003, p. 290-291), who wrote a book about the role of constants in explaining reality, wrote in the conclusion:

"... Our discovering of the patterns by which Nature works and the rules by which it changes led us to the mysterious numbers that define the fabric of all that is. The constants of Nature give our Universe its feel and its existence. ... The constants of Nature are the ultimate bulwark against unbridled relativism. They define the fabric of the Universe in a way that can side-step the prejudices of a human centered view of things. If we were to make contact with intelligence elsewhere in the Universe we would look first to the constants of Nature for common ground...."

This is extremely important explanation. The constants exclude any rampant relativism. Adversaries in the social sciences are generally not able to agree on their conflicting views and present their own narratives. In the different type of science researchers come to the recognized theory and the resulting computational methods, which ensure the effective implementation of projects and the progress of civilization. ECPG enables the measurement of human capital and the creation of the theory of fair remuneration and it indicates reasonable size of the rates of profit, as well as the interest rates and discount rates. This constant is also an important component of the general capital model. The ECPG works against unbridled relativism.

\section{Category of capital and a human capital measurement model}

The long history of research on the category of capital shows the enormous difficulty with understanding this abstract concept. R. M. Solow (1963 p. 10) wrote "... that it is a very significant that if the issue remains a theoretical discussion and unresolved after 80 years, the suspicion arises that it is badly posed or very deep indeed ..., , Recall also that Ch. Bliss, A.J. Cohen and G.C. Harcourt (2005) in their three volumes book under the title: "Capital Theory" collected 71 scientific articles, chapters, monographs, letters from the nineteenth, twentieth and twenty-first century, where the authors presented their own views on the theory of capital. The differences of opinions were so large that they have authorized the authors to formulate their opinion, that the theory of capital is infamous subject since still are the notoriously recurrent controversy around it. Ch. Bliss (1975 p. 7) even wrote:

"When economists reach agreement on the theory of capital they will shortly reach agreement on everything. Happily, for those who enjoy a diversity of views and beliefs, there is very little danger of this outcome. Indeed, there is at present not even agreement as to what the subject is about".

Why such a long-lasting difficulties exists, despite already in 1494 year L. Pacioli (1494) published his book in which appears an abstract category of capital and the basic double-entry equation. The purpose of this accounting system was, and still is, a periodic measuring of increase of the initial capital invested in the economic processes, i.e. income. Moreover, the use of the double-entry accounting soon became the norm, and economic history researchers (Rosenberg\&Birdzell 1994, p. 186-189) wrote very positive opinions about the contribution of this system for the development of capitalism. The essence of double-entry accounting is the duality of assets and capital. A full interpretation of the fundamental accounting identity includes the article (Dobija\&Kurek 2013). According to it, if a driver starts a business on 
his own account and buys a car for, say, $90000 €$, his assets (his car) have a value of $90000 €$. The balance sheet also include the value of the initial capital of $90000 €$. This car is firm, concrete and tangible; these are the characteristics of the assets. Capital embodied in this car is, however abstract and demonstrates the ability of this car to work, i.e. to drive. Generally speaking capital is the ability of doing work. When the car would lose the ability to riding, it becomes scrap, when the company will not be able to perform the work, which is to generate profits, becomes bankrupt, when a person does not have the ability to perform any work; it means that he is dead. Therefore, the category of capital is the most important economic category, and the economics is the study about capital, profits and sharing.

Deliberation leads to conclusion that capital is an abstract, homogeneous and potential category; so capital contained in the car, cash, human resources did not distinguish anything. Capital subjects to the fundamental principles (Dobija 2007), and two of which: capital cannot be created and capital relies to spontaneous random dispersion, involve thermodynamic perception of reality. Capital is a measurable category, as opposed to the resources that are only countable. The content of the capital in the assets determines its value. As a potential ability to perform the work, determines the nature of the work as a transfer of capital to the products. Thus, the potential capital and the dynamic labor are in tandem.

Understanding that the capital represents an abstract ability to do the job, and then formulate a model of changes of capital required to appeal to the fundamental principles of thermodynamics, which P. Atkins (2007, p. 3-78) defines as determinants of the development of the reality (that drive the Universe). It is easy to note that the capital is subject to the general principles. The potential is vanishing, namely: money kept in the form of banknotes lose their purchasing power, the car's value decreases every year, a bathroom after twenty years of use requires a major repair, etc. On the other hand, capital cannot be created out of nothing. And so, to do the work, one must have the ability to do the job, i.e. human capital. To open a deposit in a bank and expect percentages we must have initial capital. In order to receive a high salary a relatively large human and intellectual capital (for example, recognized surgeon) is needed. It was never seen that useful things were created out of nothing, on the contrary, are the result of the work, and i.e. transfers of capital.

A simplified model of changes in initial capital is the compound interest formula with a specific interest rate structure, as shown in (Dobija, 2007 p. 780-787), (Dobija\&Kurek, 2013). This formula determines the growth of start-up capital $(\mathrm{C} 0)$ as a function of elapsing time (t) and interest rate (r). The formula comes in two varieties: the periodic capitalization and the continuous capitalization, i.e. respectively $\mathrm{Ct}=\mathrm{C} 0(1+\mathrm{r}) \mathrm{t}$ and $\mathrm{Ct}=\mathrm{C} 0$ ert. Taking into account the current state of knowledge we identify three factors affecting the initial capital:

$\mathrm{C}_{\mathrm{t}}=\mathrm{C}_{0} \mathrm{e}^{\mathrm{rt}}=\mathrm{C}_{0} \mathrm{e}^{(\mathrm{p}-\mathrm{s}+\mathrm{m}) \mathrm{t}}$ and $\mathrm{E}(\mathrm{s})=\mathrm{p}=0,08[1 /$ year $]$

Where: $\mathrm{p}$ - is ECPG a constant of potential growth; $\mathrm{s}$ - indicates the rate of random, spontaneous diffusion of capital, and $\mathrm{m}$ - determines the increase in capital as a result of its supply by work. Interpretation of the factors affecting the growth rate of capital is as follows:

- $\mathrm{e}^{\mathrm{pt}}$ - the factor that determines the natural potential of capital growth, in line with $\mathrm{ECPG}=\mathrm{p}=0.08$ [1/year]

- $\mathrm{e}^{\text {-st }}$ - random factor determining the spontaneous diffusion of capital (the impact of thermodynamic arrow of time), $\mathrm{t}-$ flow of time;

- $\mathrm{e}^{\mathrm{mt}}$ - indicates and enhances the growth, thanks to the transfers of capital through various kind of labor accomplished by capital embodied in employees and assets.

This does not mean that the structure of the rate of growth is ultimately explained, however, identification of the factors is justified by knowledge about the fundamental laws. One can only consider two opposite influences on the initial capital. The first is the de- clining diffusion (-s) of initial capital, and the second is increasing of the concentration of the capital by work transfers. Then constant $\mathrm{p}$ is then an argument of labor function. Then:

$\mathrm{C}_{\mathrm{t}}=\mathrm{C}_{0} \mathrm{e}^{\mathrm{rt}}=\mathrm{C}_{0} \mathrm{e}^{[\mathrm{m}(\mathrm{p})-\mathrm{s}] \mathrm{t}}$ and $\mathrm{E}(\mathrm{s})=\mathrm{p}=0.08[1 /$ year $]$

From the model ( $1 \mathrm{a}$ and $1 \mathrm{~b}$ ) a formula of measuring human capital is derived, by understanding that work of parents and other professionals eliminates dispersing factor affecting infants and children, so that the ECPG is an alone factor of influence. Therefore ECPG serves as the capitalization rate of living costs, as it is shown in the presented earlier calculations (Table 1).

Model of human capital measurement is as follows:

$H(T)=K+E+D(T)+R$

Where:

- $\mathrm{H}(\mathrm{T})$ - denotes measure of employee's human capital (EHC) with $\mathrm{T}$ years of professional work;

- $\mathrm{K}$ - capitalized cost of living at rate $\mathrm{p}=0.08$ by $\mathrm{n}$ years, up to attain a capability of doing professional work;

- $E$ - capitalized cost of professional educations at rate $p=0,08$ by $m$ years, until to attain to capability of doing professional work;

- $\mathrm{D}(\mathrm{T})$ experience capital, $\mathrm{D}(\mathrm{T})=(\mathrm{K}+\mathrm{E}) \times[1+\mathrm{Q}(\mathrm{T})]$, where $\mathrm{Q}(\mathrm{T})$ is adjusted learning curve as discussed in (Dobija 2000);

- $\mathrm{R}$ - Creativity capital determined eventually utilizing market values.

Testing the EHC measurement model is carried out via wage determined on the basis of the model (2). The basis of the empirical tests is the real constant wages of employees' or information obtained in the centers for people looking for jobs (Cieślak $2008 \mathrm{p}$. 289-303), (Renkas 2012).

\section{The fair permanent compensation. An ac- ceptable size of the bonus fund}

The equation of the internal rate of return (IRR) written for EHC for one year allows for determination the total remuneration $\mathrm{W}$ as a function of EHC. The IRR equation is as follows:

$\mathrm{H}(\mathrm{T})(1+\mathrm{r})=\mathrm{W}+\mathrm{H}(\mathrm{T}+1)$

Where $\mathrm{W}$ denotes the yearly earnings and the $\mathrm{r}$ is a rate of return. From the equation (3) we get formula of $\mathrm{W}$ :

$\mathrm{W}=\mathrm{H}(\mathrm{T})(1+\mathrm{r})-\mathrm{H}(\mathrm{T}+1)$

Hence we get formula:

$\mathrm{W}=\mathrm{r} \times \mathrm{H}(\mathrm{T})-[\mathrm{D}(\mathrm{T}+1)-\mathrm{D}(\mathrm{T})]=\mathrm{r} \times \mathrm{H}(\mathrm{T})-\Delta \mathrm{D}(\mathrm{T})$

This means that the remuneration is determined by the percentage of EHC, and it reduces the growth of work experience in the current year. For a fixed salary the percentage $r$ is well known; on the basis of knowledge that determines the fair wage $r=p=E C P G=$ 0.08 [1/year]. Reducing wages by $\Delta \mathrm{D}(\mathrm{T})$ is natural and universal, because an employee gains experience as a side effect of the work, and this work provides an organization. This reduction is greatest at the beginning of employee's career, when the experience grows fastest.

Many economies, including the Polish economy, are too low work productivity in order to reach the level of the fair minimum wage. This is an empirical statement introduced by M. Dobija (2011) that the obedience of fair and legal minimum wage exists in countries with labor productivity $\mathrm{Q}=\mathrm{GDP} / \mathrm{W}$ greater than 2.8 . The approximate analytical formula estimates the percentage of the minimum pay compliance $\mathrm{CON}$ as a function of labor productivity Q by formula: 
$\mathrm{CON}=56.24+85.30 \times \lg _{10}(\mathrm{Q})$

Therefore, the first and constant economic task for many countries, as for instance Poland, is to ensure the growth of the labor productivity. At present for Poland, the $\mathrm{Q}$ does not exceed 2.0; therefore, consistency of the legal pay and the fair pay does not exceed $85 \%$. One can also work towards increasing the minimum wage by using knowledge of the wage Gina index, which in Poland reaches too high level in relation to Western Europe.

Topics of human capital measurement and relevant constant pays are seriously tested by numerous studies conducted by various authors. Besides the cited authors there are papers by: I. Cieślak (2008, p. 289-303), O. Koshulko (2012), D. Dobija (2003, p. 117 163), W. Kozioł (2009), and J. Renkas (2012). The amount of the constant pay is a part of a job agreement. It is worth to note that assigning to an employee a pay determines virtually his/her potential power. It is consistent with general knowledge that labor $\mathrm{L}$ is measured as product of power and time; $\mathrm{L}=$ power $\times$ time. Here the coefficient of power is the quotient $\mathrm{H}(\mathrm{T}) / \mathrm{Hmax}$, where Hmax is a human capital of the employee with the greatest human capital.

An important part of the employee's earnings is a performance bonus. Research made by W. Kozioł (2011, p. 47-80) has shown that if the fair constant wage specifies the $8 \%$ of the capital, the average salary of an employee in a normally prosperous company reaches $10 \%$ of EHC. Thus, the premium of $25 \%$ of basic salary is a significant addition of welfare for families with two working parents. Knowledge about human capital measurement allows also specifying the bonus fund in a size adequate to the economic performance of the organization. For this purpose, a natural cost function of production is the starting point. The essence of this function and its macroeconomic application are contained in the article (Dobija 2012). It is represented by the formula:

$\mathrm{P}=\mathrm{K}(1+\mathrm{r})=\ldots=\mathrm{W}(1+\mathrm{r})([1+(\mathrm{A} / \mathrm{H}) \times(\mathrm{z} / \mathrm{u}))=\mathrm{W} \times \mathrm{Q}$

Where: $\mathrm{P}$ - value of yearly production in market prices, $\mathrm{K}$ - total costs of production and management, $\mathrm{W}$ - total remunerations, $\mathrm{r}$ cost profitability, $\mathrm{A}$ - an average value of assets, $\mathrm{H}$ - total value of $\mathrm{EHC}, \mathrm{z}$ - ratio of turnover of assets, $\mathrm{u}$ - percentage of pay in respect to EHC.

On the basis of production function (7) is formed the production model by utilizing formulas $\mathrm{e}^{\mathrm{a}} \approx 1+\mathrm{a}$. Then substituting for set of variables $(\mathrm{r}, \mathrm{z}$, and $\mathrm{u})$ a one synthetic variable $\mathrm{M}$ (called management) we get model of production. This variable synthesizes impacts defined as: profitability of cost, asset turnover, and the percentage of pay for work in respect to EHC of all employees. These variables are subject to the current managerial decisions as opposed to long-term variables such as: assets $\mathrm{A}$ and $\mathrm{H}$. We get a model:

$$
P=W \times \exp \left[\frac{A M}{H}\right]
$$

Utilizing formula $\mathrm{L}=\mathrm{p} \times \mathrm{H}$, where $\mathrm{L}-$ value of constant compensations, and $\mathrm{p}=\mathrm{ECPG}$, we eliminate the variable $\mathrm{H}$ by easier accessible variable $\mathrm{L}$. Then we get formula:

$$
P=W \times \exp \left[\frac{A M p}{L}\right]
$$

Model (9) is capable to determine the fund for bonus wage. Assuming a natural condition that the variable $M$ ought not to decrease, which means that the profitability of the cost and speed of rotation of assets are maintained, despite a possible increase in wages, we get equation (9) with one unknown variable. Thus, the formula for determining the total amount of remuneration is:

$W=P \times \exp \left[-\frac{A M p}{L}\right]$

Formula (10) allows determining the remuneration budget as a function of the planned economic performance. If a budged of production and sale will be accomplished by the unabated variable management $\mathrm{M}$, the amount of $\mathrm{W}$ - $\mathrm{L}$ determines the size of the bonus fund. Therefore the size of variable $\mathrm{M}$ calculated for the first year is the starting point. For planning purposes, it is assumed that $\mathrm{M}$ in the next year cannot be reduced what makes it as a given parameter. Of course a management may adopt a policy of systematic increase in that variable. This will mean that the profitability of costs and the turnover ratio will not decline, and the fixed pays increases will be adequate to the financial results of organization.

\section{Natural economics driven by labor. money as a work receivable}

The essence of money - goods economy is a continuous market confrontation of two streams, which are activated by the potential of human capital and its work, as it is shown in diagram 1. The first stream (left side) forms value of final products generated by composition of current labor of employees (W) and past work embodied in different sort of assets. The second is a stream of compensations $(\mathrm{W})$, i.e. receivables due for work. The source of these two streams is the same human capital of employees, and their edge is the market exchange of money (work receivables) to products and vice verse. This exchange can be described mathematically in the form of the equation of exchange. The streams run constantly, but to capture the quantitative relations, we use variables in the annual scale, in particular of the GDP category.

The final production exchanged on market for a given year is the value of GDP in current prices. GDP is also the product of labor costs $\mathrm{W}$ and work productivity $\mathrm{Q}$, i.e. $\mathrm{GDP}=\mathrm{W} \times \mathrm{Q}$. The $\mathrm{Q}$ is a factor of the cost production function, presented, among others, in (Dobija, 2011). The right stream determines the remuneration with all additional components, which in the annual perspective, determines the value of $\mathrm{W}$. (Bart of remuneration $\mathrm{aW}$, where $0<\mathrm{a}<1$ passes directly to market exchange. The second part of compensation stream $(1-$ a) W flows firstly to the system of commercial banks. These are savings and pension funds. In the commercial banks this stream can be increased by multiplier $\mathrm{k}$ to the volume of $(1-\mathrm{a}) \mathrm{Wk}$, due to the conducted lending and payment of pensions. Part of this inflow remains on bank accounts due to the requirements to maintain liquidity and other provisions.

Source: A modification of the diagram presented in the article $\mathrm{M}$. Dobija, (2011)

The market confrontation of these two streams (value of products and total money) finally determines the purchasing power of money and the final market value of products. Quantitative perspective of exchange of products for money (and vice versa) written in the form of the wage equation of exchange leads to indication of a relation between the introduced values. The wage equation of exchange is introduced under condition that work finances itself and generates money (work receivables), as well pension funds are a kind of savings.

Let us notice that diagram 1 encompasses the work of every employee: farmer, worker, teacher or police officer. It is easier to understand when perceiving GDP mainly as the sum of current labor and the past labor embodied in the assets measured by depreciation as discussed by M. Dobija (2014). The formula for this method of calculating GDP is as follows:

GDP $=$ Total pays + Depreciation + Taxes + Gross profits + Change in $\mathrm{Bb}$

Here the $\mathrm{Bb}$ denotes initial balances of products. This also means that summing up the indicated economic variables in the entire economy, we calculated the contribution of each economic unit regarding value added; both from the market and the public sector. The diagram 1 helps also to see how the past work serves for future time. If some employees working in their profession were building bridges, they would receive money (their work receivables on their bank account) as remuneration, and the costs of their work would become a part of the bridge value. Now, having already retired, they receive payments from capitalized retirement funds, but in the stream of products there is an amount of depreci- 
ation of the existing bridges used by the inhabitants. Similarly, a teacher and a policeman who worked for safe development of human resources increased their embodied human capital. Now a work of this human capital currently increases GDP.

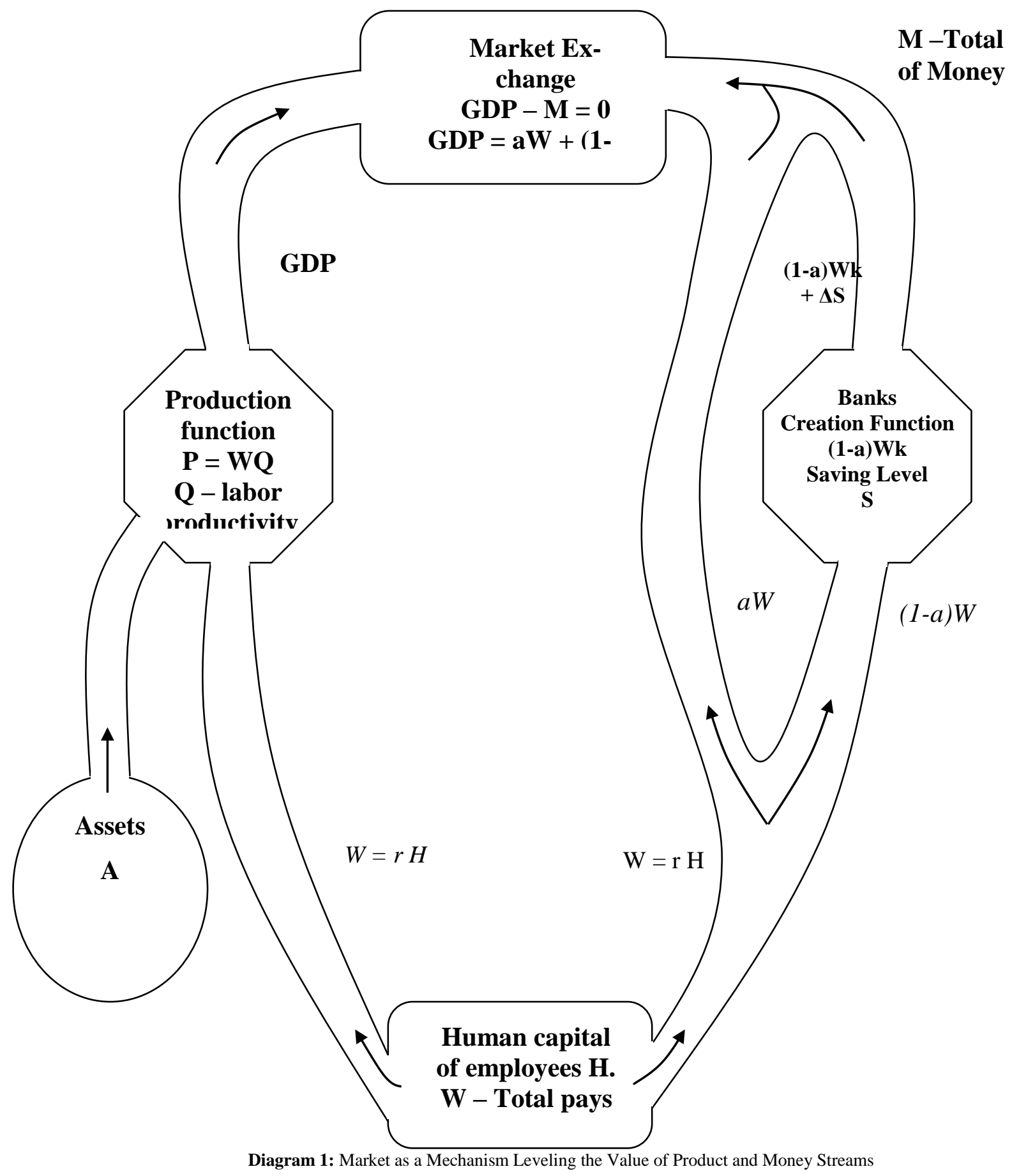

The wage equation of exchange balances the value of GDP with the sum of money M. According to the diagram 1, this equation is as follows:

$\operatorname{GDP}=\operatorname{GDPR}(1+\mathrm{i})=\mathrm{a} \times \mathrm{W}+(1-\mathrm{a}) \times \mathrm{W} \times \mathrm{k}+\mathrm{c} \times \mathrm{S}$

Or

$\operatorname{GDP}=\operatorname{GDPR}(1+\mathrm{i})=\mathrm{a} \times \mathrm{W}+(1-\mathrm{a}) \times \mathrm{W} \times \mathrm{k}+\mathrm{d} \times \mathrm{W}$

Symbols of values are as follows: GDP - nominal GDP, GDPR real GDP, $\mathrm{W}$ - labor costs, $\mathrm{Q}=\mathrm{GDP} / \mathrm{W}$ - work productivity in$\operatorname{dex}, \mathrm{Q}_{\mathrm{r}}=\mathrm{GDPR} / \mathrm{W}$ - real work productivity index, $\mathrm{i}$ - inflation rate, $\mathrm{k}$ - coefficient increasing the value of stream $(1-\mathrm{a}) \mathrm{W}$ as a result of credit action conducted by the banking system, $\mathrm{d}=$ $\mathrm{c} \times \mathrm{S} / \mathrm{W}$.

On the basis of the equation (12) the multiplier (k) is determined. With the assumption $\mathrm{i}=0$, that is the zero inflation and deflation condition, we obtain:

$\mathrm{GDP}=\mathrm{GDPR}=\mathrm{a} \times \mathrm{W}+(1-\mathrm{a}) \times \mathrm{W} \times \mathrm{k}+\mathrm{d} \times \mathrm{W}$

The equation (1b) divided by variable $\mathrm{W}$ gives:

$\mathrm{Q}=\mathrm{Q}_{\mathrm{r}}=\mathrm{a}+(1-\mathrm{a}) \times \mathrm{k}+\mathrm{d}$

Hence the formula determining the multiplier $\mathrm{k}$ is as follows: 
$\mathrm{k}=\left(\mathrm{Q}_{\mathrm{r}}-\mathrm{a}-\mathrm{d}\right) /(1-\mathrm{a})$

Therefore, the maximum of the credit stream is presented as:

Credit $=(1-\mathrm{a}) \mathrm{W}\left(\mathrm{Q}_{\mathrm{r}}-\mathrm{a}-\mathrm{d}\right) /(1-\mathrm{a})=\mathrm{W} \times\left(\mathrm{Q}_{\mathrm{r}}-\mathrm{a}-\mathrm{d}\right)$.

The above formula indicates only main macroeconomic variables, which have impact on the possibility of generating credit by commercial banks. Apart from these values there is a set of constraints, in particular the need for providing safety of a commercial bank, which seriously limits lending. Formula (16) explains that the credit value depends on: remuneration stream $\mathrm{W}$, real work productivity $\mathrm{Q}_{\mathrm{r}}$, and the wealth level (a) as well changes in savings and detriment funds. The greater is the productivity of work (depending strongly on the value of assets) the greater are the possibilities of crediting.

In this system, the central bank does not generate the cash money from nothing and has not tools to help the commercial banks. For this reason, requirements of maintaining liquidity must be strict and rigorously observed. In addition, the banking system as a guard of citizens' money must operate under permanent supervision of the state institutions. In its new role, the central bank is among others, a guard of the work productivity Q, and of the adequate size of the public sector.

The diagram 1 shows also that it is work (human capital transfer), which drives the economy. Application of the economic constant $p$ $=0.08$ protects wages against uncontrolled relativism mentioned by J. Barrow (2003, p. 290-29) in his work on the role of constants in scientific description of the world. It is demonstrated that wages resulting from the human capital measurement are fair in the sense that they prevent depreciation of the employee human capital. As commonly known, already Plato indicated that the range of wages should not exceed 5 times. According to calculations of human capital the range of fixed wages (but without considering a creativity capital) should adhere to the same proportion. It is not a case for example in Poland where the number resulting from dividing average earnings in groups of $10 \%$ with the highest and the lowest earnings is 10 times. This consideration does not involve an creativity capital. An identifiable creativity capital of an individual can be a reason of his/her extremely high earning and such a case is theoretically consistent.

In practice, it can be noticed, that often the weaker a country is economically and organizationally (with the exception of the USA, China), the greater its Gini wage index is. Using the data provided by M. Wójcik-Żołądek (2013) and other research we may indicate a group of countries with the moderate volume of the Gini index. Nordic countries: Denmark, Sweden, Finland, Norway and apart from them, Austria and Slovenia have the index below 0.27 . It is also a case of many developed Western countries. Human capital measurement enables rough assessment of the proper volume of the GINI index in respect to wage income. It was done by W. Kozioł (2009) who examined an estimated diversity the population of employees in terms of education and experience. The result of his rough estimation was 0.24 . Poland, with the real index estimated significantly above 0.3 has excessive wage inequalities.

\section{A hypothesis. The present economic system requires a money issuance corresponding to the amount of the fair compensation in the public sector}

The diagram 1 shows the natural exchange and balance, reached by the money-goods economy, when money is discerned correctly as the work receivables. Then, preventing a decrease in the work productivity measured by the ratio $\mathrm{Q}$, and keeping consistency with the designated credit volume ensures maintaining the value of money that is balance: lack of inflation or deflation. Some small inflation may appear, due to the fact that the systems for measurement and management of work processes are never perfect. On the other hand, in the present state of affairs, financing work in the public sector from taxes results in the fact, that the value of market products and services (GDP) is not a fully balanced by value of total money (M). Because of the direct taxation of remunerations the $\mathrm{M}$ is mostly less in the well controlled and developed economies. In other words the value flowing by the stream of products is significantly greater than the value flowing by the stream of money and credit.

The correct and natural economics requires that remunerations in the public sector, for example for a teacher performing his/her work should not come from any taxes, otherwise deflation may appear. Moreover his/her fair salary should not be charged by a direct tax making the pay unfair. Therefore in the correctly organized economy the salaries for the considered teacher should be generated by the institutional payer of remuneration in the public sector. This institution is endowed with the authority of issuing money for payment of the work accomplished in the public sector. In fact this institution has a power to make a double-entry record of the work receivable for the teacher. The record made by mentioned institution sets off work liabilities of a school that employs the teacher and moves the value of salary to the teacher account in a commercial bank. This institution is the reformed central bank. Labor is the transfer of human capital so labor is self-financing. To count out this fact means constant obstacles with a budget deficit and too high taxations. In such a framework the phenomenon of deflation is normal. The fact that currently deflation is not a common condition, although it does occur (Japan, USA, EU), and it affects mainly economically developed and well-governed countries, results from those extensive issuances performed by the central banks. This way, the government partially acquires money for financing work in the budget sector. In the poorly governed countries, the public sector is usually too big and often remunerations exceed the value of work, so inflation prevents deflation.

The above considerations show that in the present economic system the central bank has to constantly issue new money. The amount of necessary issuance of money can be roughly estimated using an example of the USA economy. Assuming GDP in the USA, at the level of 16000 billions \$ in 2014 and using estimation of the index $\mathrm{Q}=3.60$ (Dobija 2013) we obtain the volume of compensation $\mathrm{W}=\mathrm{GDP} / \mathrm{Q}=4444$ billion $\$$. From this, we calculate a part attributable to compensation in the public sector. To compute is used a Polish division rate of 0.23 that is very rough estimation. This percentage is likely less so let us assume 0,20 for the USA. Therefore, $4444 \times 0.20=888$ billion $\$$ as roughly estimated yearly compensations of the US public sector. Hence, the approximate amount per month is 74 billion $\$$.

This is roughly estimated value, that flows by the stream of products as shown on diagram 1, but it is partly excluded from the stream of money by direct tax. As commonly known the public sector pays are financed from taxes. This is a reason of constant excess of values in the stream of products (at least at times of peace and lack of inflation). Quantitative easing, applied by FED is thus justified, just like the statement that without money printing economy will collapse since money unit would quickly change its value in plus. Similar calculation for Poland, at $\mathrm{Q} \approx 2.0$ and $\mathrm{GDP} \approx 1600$ billions of PLN makes it possible to estimate a similar amount at 11 billion PLN per month. Calculations are to some degree consistent with practice.

In December Forbes (2014) informed that additional printing of dollars by FED will be limited:

“... American FED decided to reduce the scale of purchase of assets (treasury bonds) to the level of 75 billion USD a month. (...) Reduction in the quantitative easing programme by 10 billion dollars a month is the first step towards withdrawal from additional money printing, which so far has fostered the USA economy ..."

Does quantitative easing lead to stable value of money? This is not clear but it is a remedy. A right solution is known. The correct, natural and simple solution assumes that the reformed FED is a payer of compensation for work in the public sector, and consequently does not purchases treasury securities. Then economy has 
no increase of indebtedness, nor a budget deficit. The reformed central bank no longer prints money from nothing. In the new order, FED gains the function of an independent controller of work productivity, and thereby, of the size of the public sector. In addition, in normal economic conditions, the deficit will not arise so the USA will be able to repay their international liabilities faster.

It is not possible to state with unquestionable certainty that these rough calculations clearly indicate an economic pattern, but its real nature is supported by the cybernetics analysis (diagram 1) of capital flows. What is more, the FED focusing on an inflationary target, determines the amount close to 75 billion USD a month as a necessary constant issuance. The quantitative easing raises this amount and is necessary from time to time. Computation made in case of the USA is in some way realistic since a consistency of compensation to the value of work is a significant feature of this economy.

The introduced explanation indicates significant flaws of the money-goods economy in the scope of the most important issue that is money. Persistent building of the theory without proper consideration to the triad of capital, labor, and money resulted in the defective equation of exchange, with a bizarre category of "money amount". Money does not circulate nor is material. Diagram 1 and the wage equation of exchange correctly present the main relations, showing the inalienable role of the work productivity index $\mathrm{Q}$ in solving the issues of inflation, credit and remuneration. An important role is also played by the theory of measurement human capital and the knowledge about the fair wages.

The presented thoughts are to some extent convergent with an idea known as "helicopter money" (Bossone et al. 2014). Simply speaking this is the idea of overt financing the budget deficit by central bank. One can say that the overt money financing is the policy with the highest effect in raising demand and GDP without increasing the public debt. Of course it is better to do so instead of feeding commercial banks with empty money with hope that the banks will change them to the firm valuable money. It is however a significant step forward together with a small step aside. Money has to arise as result of an effective labor is the firm theoretical statement. Therefore the central bank should not produce money for all government spending as for instance purchasing of assets or a war preparation.

\section{Concluding remarks}

The deflation comes from reducing the fair remunerations with direct taxes, in order to finance work in the public sector. The presented considerations lead to an important opinion that deflation may appear and gain momentum in the present state of economy and knowledge, which does not make use a natural phenomenon of self-financing of work. In the present economics payment for work in the public sector from taxes reduces the stream of money confronting the stream of products which, however, contains the value of indispensable effective work performed in the public and family sectors of the economy. This is a reason why the central bank must still issue new money with hope that demand and output will rise. This is also a reason of the budget deficits.

To achieve the natural self-regulation in economy, the traditional functions of central banks are incorrectly established, so there is a need for a reform as is showed on the scheme 1. The main task of the reshaped central bank is its role of the payer of remuneration for the public sector. In addition the central bank serves as an independent agency controlling the productivity of work in the economy as well the size of the public sector. The reformed central bank does not issue money from nothing in contradiction to the fundamental laws of our reality but this institution pays for accomplished work. It is the essence of a new economic order, that is to say the economics driven by labor. This is also the economy where Say's law is not disturbed so that the value of production is consistent with the value of remuneration making sufficient demand and maintaining a stable value of money unit. It does not mean that an exchange rate will be stable since it depends from labor productivity parity.

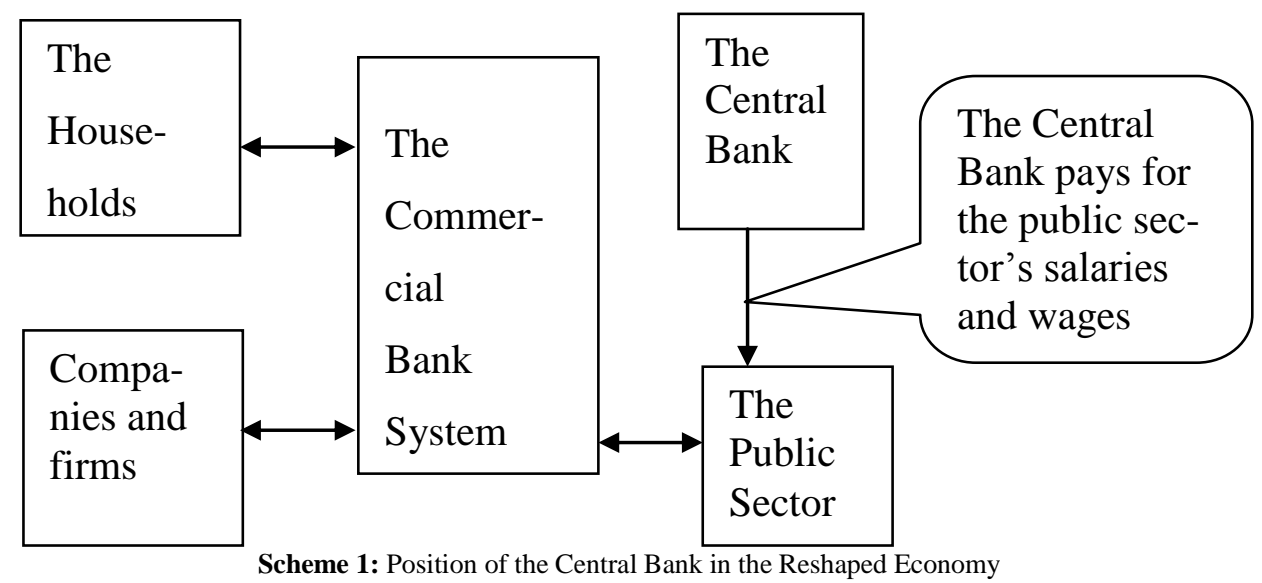

Source: Dobija M (2011) Abstract Nature of Money and the Modern Equation of Exchange, Modern Economy, Vol. 2, No. 2, 142152. (DOI: $10.4236 / \mathrm{me} .2011 .22019$ )

An essential part of new theories is the phenomenon of labor selffinancing. It liberates an economy from a significant part of tax burdens and leads to a deficit-less economy as well. There is only one requirement. Namely, bringing to the end the cash money and recognizing the indispensable fact that money arises exclusively by labor. The money-goods economy is a great human achievement under condition that the triad: capital-labor-money is completely recognized and respected. Then human capital becomes a means of increasing value; that is to say, for creating well-being. Since human capital develops in a family unit, that's where the economics starts. Therefore, the family sector is an essential part of the economy and has serious responsibilities, comparable to that assigned to other sectors. Nonetheless, a correct valuation of human capital and an attention to fairness of compensation is the responsibility of country authorities.

\section{References}

[1] Atkins P (2007) Four Laws that Drive the Universe. Oxford University Press, New York.

[2] Barrow JD (2003) From Alpha to Omega. The Constant of Nature. Vintage Books, London.

[3] Baumol WJ (1999), Retrospectives Say's Law. Journal of Economic $\begin{array}{llllll}\text { Perspectives, } & \text { Vol. } & 13, & \text { No } & 1 & 195-204\end{array}$ http://dx.doi.org/10.1257/jep.13.1.195.

[4] Bliss Ch (1975) Capital Theory and the Distribution of Income. North-Holland Publishing,Oxford.

[5] Bliss Ch, Cohen AJ, Harcourt GC (2005) Capital Theory, Vol. I-III, Edward Elgar Publishing Limited, Northampton, Massachusetts. 
[6] Bossone B, Fazi T, Wood R (2014) Helicopter money: The best policy to address high public debt and deflation, VOX CEPR's Policy Portal, http://www.voxeu.org/article/.

[7] Cieślak I, Dobija M (2007) Teoretyczne podstawy rachunkowości kapitału ludzkiego. Zeszyty Naukowe UEK, No 735, 5-24.

[8] Cieślak I (2008) Value of Human Capital and Wage Disparities, In General Accounting Theory Evolution and Design for Efficiency (Górowski I ed). Wydawnictwa Akademickie i Profesjonalne, Warsaw, pp 289-303.

[9] Dobija D (2003) Pomiar i sprawozdawczość kapitału intelektualnego przedsiębiorstwa, Wydawnictwo WSPiZ, Warsaw.

[10]Dobija M (1998) How to Place Human Resources into the Balance Sheet, Journal of Human Resource Costing \& Accounting, Vol. 3, No. 1, 83-92. http://dx.doi.org/10.1108/eb029044.

[11]Dobija M (2000) Human Resources Costing and Accounting as a Determinant of Minimum Wage Theory, Zeszyty Naukowe UEK, No 553, 36-61.

[12]Dobija M (2007) Abstract Nature of Capital and Money. In New Developments in Banking and Finance (Cornwall LM ed.) Nova Science Publishers, New York, pp.89-114

[13]Dobija M (2011) Abstract Nature of Money and the Modern Equation of Exchange, Modern Economy, Vol. 2, No. 2, 142-152. (DOI: 10.4236/me.2011.22019) http://dx.doi.org/10.4236/me.2011.22019.

[14]Dobija M (2011) Labor Productivity vs. Minimum Wage Level, Modern Economy, Vol. 2, No. 5,780-787. (DOI: 10.4236/me.2011.25086) http://dx.doi.org/10.4236/me.2011.25086.

[15]Dobija M (2012) Antykryzysowe zarządzanie produktywnością pracy, Organizacja i Kierowanie, No1 (150), 115-130.

[16]Dobija M (2014) Pomiar aktywności ekonomicznej państwa, Zeszyty Teoretyczne Rachunkowości, No. 75(131), 7-22. http://dx.doi.org/10.5604/16414381.1098720.

[17]Dobija M, Kurek B. (2013) Scientific Provenance of Accounting, International Journal of Accounting and Economics Studies, Vol. 1, No 2, 16-24, (DOI: $10.14419 /$ ijaes.v1i2.1054) http://dx.doi.org/10.14419/ijaes.v1i2.1054.

[18]Forbes (2014) FED ogranicza dodruk pieniądza giełda reaguje wzrostem, http://www.forbes.pl/, (Accessed September 20, 2014).

[19]Goetzmann WN, Ibbotson RG (2005) History and the Equity Risk Premium. Yale ICF Working Paper No. 05-04. SSRN: http://ssrn.com/abstract=702341.

[20]Hutt WH (1974) A Rehabilitation of Say's Law, Ohio University Press: Athens.

[21]Kates S (1998) Say's Law and Keynesian Revolution. How Macroeconomic Lost its Way, Edward Elgar, Cheltenham.

[22] Koshulko O (2012) Examining a level of minimum wage in Ukraine and an influence on human capital development. (In Russian), Ekonomiczeskij Analiz: Teoria i Praktyka, No. 7 (262), 65-76.

[23]Kozioł W (2011) Rozwój rachunku kapitału ludzkiego, In Kapitał ludzki w perspektywie ekonomicznej (Dobija M ed.), Wydawnictwo Uniwersytetu Ekonomicznego w Krakowie, pp. 47-80.

[24]Kozioł W (2009), Struktura wiedzy w społeczeństwie jako determinanta godziwych nierówności płacowych w gospodarce, Zeszyty Naukowe Uniwersytetu Ekonomicznego w Krakowie Nr 796, 21-32.

[25]Kozioł W (2010) Kształtowanie płac stałych na podstawie kapitału ludzkiego,In Teoria pomiaru kapitału i zysku (Dobija $\mathrm{M}$ ed.) Wydawnictwo Uniwersytetu Ekonomicznego w Krakowie, (2010), pp. 73-100.

[26]Kurek B (2011) Hipoteza deterministycznej premii za ryzyko, Wydawnictwo Uniwersytetu Ekonomicznego w Krakowie, Kraków.

[27]Kurek B, Dobija M (2013) Towards Scientific Economics, Modern Economy, Vol. 4, No. 4 293-304. (DOI: 10.4236/me.2013.44033). http://dx.doi.org/10.4236/me.2013.44033.

[28] Pacioli L (1494) everything about Arithmetic, Geometry and Proportion (original title: Summa de Arithmetica, Geometria, Proportioni et Proportionalita), Venice.

[29]Pikulska-Robaszkiewicz A (1999) Lichwa w państwie i prawie republikańskiego Rzymu, Wydawnictwo Uniwersytetu Łódzkiego, Łódź.

[30]Renkas J (2012) Empiryczny test modelu kapitału ludzkiego i minimalnych wynagrodzeń, Nierówności społeczne a wzrost gospodarczy, No 24, 280-291.

[31]Rosenberg N, Birdzell LE (1994) Historia kapitalizmu, Signum, Kraków.

[32] Solow R (1963) Capital Theory and the Rate of Return, NorthHolland Publishing Company, Amsterdam.

[33]Wójcik-Żołądek M (2013) Nierówności społeczne w Polsce, Infos, Biuro Analiz Sejmowych, No. 20(157), 1-5

[34]Wright R (2000) NONZERO. Logika ludzkiego przeznaczenia, Prószyński i S-ka, Warszawa. 